\title{
Theologians as Cultural Brokers: Transatlantic Translation of Ideas during the Emergence of Liberation Theology
}

\author{
Antje Schnoor (D) \\ German Research Foundation (DFG), Kennedyallee 40, 53175 Bonn, Germany; antjeschnoor@gmx.de
}

Citation: Schnoor, Antje. 2021.

Theologians as Cultural Brokers:

Transatlantic Translation of Ideas during the Emergence of Liberation Theology. Religions 12: 406. https://doi.org/10.3390/rel12060406

\section{Academic Editors:}

Wilmer Estrada-Carrasquillo and Yenny Delgado-Qullaw

Received: 4 May 2021

Accepted: 27 May 2021

Published: 1 June 2021

Publisher's Note: MDPI stays neutral with regard to jurisdictional claims in published maps and institutional affiliations.

Copyright: (C) 2021 by the author. Licensee MDPI, Basel, Switzerland. This article is an open access article distributed under the terms and conditions of the Creative Commons Attribution (CC BY) license (https:// creativecommons.org/licenses/by/ $4.0 /)$

\begin{abstract}
The paper sheds light on the transatlantic theological discourse during the emergence of liberation theology. It conceptualizes this discourse as a transatlantic communication process reframing it as a transfer and translation of ideas and concepts. Starting from this perspective, I prove the assumption that the transatlantic theological discourse reflected a Latin American claim to academic equity and I show that European reactions to liberation theology implied answers to that claim. As the focus is on the relationship between Latin America and Europe, the article illustrates the significant role of relationships marked by different forms of dependency (economic, political, intellectual) in the development of liberation theology. Furthermore, the paper argues that for a deeper understanding, it is misleading to speak about Latin American theologians on the one hand and European theologians on the other hand, as if it was about clear-cut groups with homogenous motivations, positions, and goals. On the contrary, there were advocates and opponents of liberation theology on both sides of the Atlantic who moreover formed transatlantic alliances. The paper calls those theologians cultural brokers, since they communicated and mediated across the Atlantic.
\end{abstract}

Keywords: liberation theology; contextual theology; intellectual history; postcolonial studies; decoloniality studies; translation of ideas; diversity; transatlantic history

\section{Introduction}

Scholars dealing with intellectual history in Latin America are confronted with a traditional narrative which assumes a lack of independent conceptual development in the subcontinent. This narrative is rooted in the age of nation building and constitution drafting since the second decade of the 19th century. ${ }^{1}$ Political and academic developments in Latin America are-especially from a European perspective-often regarded as involving European ideas. This is also true for the development of liberation theology. Those scholars who question the Latin American roots of liberation theology often stress the fact that a good amount of liberation theologians studied in Europe and were affected by the 'new' political theology of Johann Baptist Metz and other European theologians.

Less attention is paid, in contrast, to how ideas were transferred in the other direction, that is to say, from Latin America to Europe. With regard to the transfer of theological ideas, a remarkable example is the adoption of Latin American liberation theology in the Jesuit order, namely into the decrees of the 32nd General Congregation in 1974/75 (Schnoor 2011).

The present article aims to shed light on the transatlantic theological discourse during the emergence of liberation theology and conceptualizes this discourse as a transatlantic communication process, reframing it as a transfer and translation of ideas and concepts. Starting from this perspective, I prove the assumption that the transatlantic theological discourse reflected a Latin American claim to academic equity, and I show that European reactions to liberation theology imply answers to that claim. By focusing on the relationship between Latin America and Europe, the paper shows the significant role of dependency relationships in the development of liberation theology and argues that liberation theology had an emancipatory meaning. 
The hegemonic position of Europe within the transatlantic theological discourse, or the "colonial difference" (Mignolo 2008) as Walter Mignolo would call it, has to be taken into account. Nevertheless, it is problematic to speak about Latin American theologians on the one hand and European theologians on the other hand, as I do in this article, as if it was about clear-cut groups with homogenous motivations, positions, and goals. The opposite is true. There were advocates and opponents of liberation theology on both sides of the Atlantic who moreover formed transatlantic alliances. Especially because of this fact, it seems justified to me to call those theologians cultural brokers. Culture is understood here out of a deconstructionist perspective denying a pre-given essence of cultural identity. It is rather a narrative without any historical origin (Buden et al. 2009, p. 198). The cultural or colonial background is a category of difference which is closely entangled with power. As well as other categories of difference like gender, class, or age, the cultural or colonial background is a social construct which makes us ascribe power and competence to one group and to deny it to the other. I use the denominations "Latin American" and "European" theologians to document these relationships of inequality and to examine how cultural categories are constructed within the communication process. In so doing, the cultural categorization serves heuristic aims; nevertheless, those categories are not conceptualized as permanently fixed. Thus, the article focuses on the meta-communication of the transatlantic academic discourse, combining approaches of intellectual history with communication theory. Since I do that out of an irreducible European perspective, I also have to take into account the meta-communication of the academic discourse I am participating in with this article.

The present article begins by outlining that the transatlantic theological discourse was a transfer and translation of ideas in both directions and by explaining the term "cultural brokers".

\section{Contact Zones between Theological Cultures and Concepts}

The General Conference of the Latin American Episcopate in 1968 in Medellín discussed those theological concepts which were later named an "option for the poor" and became closely connected to Latin American liberation theology. Liberation theology was a reaction to poverty and social injustice and can be understood as a further development of the church's social doctrine. ${ }^{2}$ Most well-known Latin American liberationist theologians, for example, Gustavo Gutiérrez, Hugo Assmann, Leonardo Boff, and Juan Luis Segundo, completed at least part of their studies at European universities and were affected by European theologians such as Karl Rahner, Edward Schillebeeckx, or Johann Baptist Metz (Dussel 1995, pp. 106ff; Kruip 1997, p. 47). The Argentine philosopher and theologian Enrique Dussel describes in detail the impact of the study period in Europe for some of the famous theologians of his generation, especially the studies in France and Belgium (Dussel 1995, pp. 108f). In particular, about a dozen known liberation theologians studied at the Catholic University in Leuven in the 1950s and 1960s (Moews 2002, pp. 18f). In Leuven, they became acquainted with such new theological developments as the Nouvelle Théologie and the theology of Karl Rahner, among others.

Nevertheless, it was not a one-sided transfer of ideas and concepts from Europe to Latin America. On the contrary, there was a broad adaptation of Latin American ideas and approaches in Europe-and also in other parts of the world-especially in conjunction with liberation theology. As already mentioned, an important example is the 32nd General Congregation 1974/75 of the Jesuit order. In decree 4 of this General Congregation, the Society of Jesus declared the promotion of justice in addition to evangelization as the basic mission of Jesuits. ${ }^{3}$ This decree shows clear similarities to the Latin American liberation theology, in particular the emphasis on the existence of structural injustice and above that, the concept and the definition of church and the concept of priest corresponded to liberation theology (Schnoor 2011, p. 427). Already before the 32nd General Congregation, elements of liberation theology had been adopted in different ecclesiastical documents of the institutional church, such as in the final document of the II Latin American Episcopal 
Conference in Medellín 1968 and into the document "De iustitia in mundo" ("Justice in the world") of the Synod of Bishops in 1971 (Collet 1994, p. 131).

Within contemporary history of theology, this is an example of a two-fold transatlantic translation of ideas. The fact that several Latin American theologians studied in Europe was used by some European academics to discredit liberation theology. They refused to deal with it in a serious way since they did not understand it as an independent concept, but just as a result of an export of the political theology of Johann Baptist Metz. Therefore, the strategy was, according to Gerhard Kruip, to criticize liberation theology together with the new political theology without differentiating between them. ${ }^{4}$

Instead of asking for an assumed origin of theological ideas and concepts, I understand theologians on both sides of the Atlantic - at least those who participated in the discourse in a constructive way-as cultural brokers, as mediators who translate theological knowledge from one cultural context into the other and may combine it with new elements. ${ }^{5}$ Cultural brokers are familiar with, if not at home in, different knowledge cultures. ${ }^{6}$ This is especially true for Latin American theologians who were trained in European theology and quite often passed their studies in Europe, and were therefore multilingual. Even before the emergence of liberation theology, they served as translators between European theology and the religious and historical knowledge of Latin American Catholicism.

However, European theologians can also be described as cultural brokers. Some of them realized both the reciprocity and the openness or contingency of these processes of translation and adaptation. Referring to the reciprocity, Johann Baptist Metz wrote 1973 in the preface of the German translation of Gutiérrez' Liberation Theology that Gutiérrez (1976) may borrow ideas from European theology, but that nevertheless his book puts an end to the "usual one-way road in the relationship between European and Latin American Theology". ${ }^{7}$ Furthermore, Karl Rahner wished the transatlantic dialogue to be open and constructive and called liberation theology in 1977, a "salutary uncertainty, a beneficial challenge and a duty for us" ${ }^{8}$ It is noteworthy that precisely those theologians claimed to be inspired by Latin American ideas, when, according to the argument of some critics of liberation theology, they should have seen those ideas and concepts as a mere reflection of their own approaches. By doing so, they refuted the critics' argument and emphasized the innovation by Latin American approaches.

The translation of ideas cannot be understood, either on one or the other side, as an adoption of self-contained concepts, but rather as a selection and further development of transferred ideas and their application in their own cultural context. This is to say that there remained differences after the translation processes. Ideas of the European new political theology changed while being translated and made suitable for Latin American liberation theology, while ideas of liberation theology changed while being translated in Europe, for example during the 32nd General Congregation of the Jesuit order. Processes of translation allow elements which are supposed to be translated to be acknowledged and embraced, but also to be rejected (Wagner, p. 6).

\section{Parallel Intellectual Movements of Liberation Theology: Dependency Theory and Liberation Philosophy}

Several Latin American theologians indicated the importance of their studies in Europe. Nevertheless, it is a common line of argument to point to the Latin American originality of liberation theology and to refuse the translation of European ideas. What may be the reason for the limited acknowledgement of the processes of translation? In order to understand this, it is useful to consider the historical context of the emergence of liberation theology. The parallels and links to other intellectual and academic developments during the 1960s and 1970s are striking, in particular the parallels to dependency theory and to the philosophy of liberation. These developments in Latin America not only have similarities with regard to content, but, as we will see, also have an emancipatory impulse in common.

Dependency theory emerged alongside liberation theology in the 1960s. According to this theory, the economic underdevelopment of the Third World resulted from the dissymmetric relationship between the economically backward countries and the industrial 
nations within the global economic system. Due to the international division of labor, the countries in the periphery depended on the industrial centers. Dependency theory contradicted modernization theory which regarded underdevelopment as a historical stage to overcome on the way to development. Instead, representatives of dependency theory argued that development and underdevelopment are simultaneous processes that mutually generate each other. ${ }^{9}$ Since dependency theory was based on the Marxist analysis of society, it "Latin-Americanized" Marxism, as it was called by Enrique Dussel (1995, p. 111).

However, dependency theory was closely linked to liberation theology, which adopted the basic assumptions of this new economic theory and used it to analyze society. ${ }^{10}$ Similar to liberation theology, representatives of dependency theory tend to emphasize that this theory had its origins in Latin America, though its Latin American founders were in close contact with European intellectuals. One of these European intellectuals is Johan Galtung, whose works have been acknowledged by Latin American dependency theorists, but who himself was affected by his research in Latin America and by the ideas of dependency theorists.

These intellectual developments can also be interpreted as processes of translation of economic and social ideas across cultural and geographic borders. Nevertheless, the claim to originality of some Latin American intellectuals may also be a reaction to the fact that intellectual originality is often exclusively ascribed to Europeans. This is true, for example, for the term "structural violence", which is commonly ascribed to Johan Galtung and which he introduced in an article in 1969 (Galtung 1969). The concept behind this term, however, was already discussed in Latin America before Galtung's publication, though under the term "institutional violence" (Schnoor 2013, pp. 255-58), for example, in 1968 by the Chilean Jesuit journal Mensaje (Editorial (174) 1968, pp. 531-32; Vekemans n.d., p. 178). The definition of the term institutional violence corresponded largely to the definition of structural violence. The cultural and intellectual 'contact zone' may have been the Jesuit research center Bellarmino where the journal Mensaje belonged and which was visited by Galtung in 1963 (Vekemans n.d., p. 178).

Out of the perspective of intellectual history, we can find a parallel to liberation theology and dependency theory in Latin American philosophy. At the end of the 1960s, more or less simultaneously to the emergence of liberation theology, the Latin American philosophy discourse revisited the question for its assumed own "origins". The question of the constitution and fundament of an "American philosophy" was already raised in the 1830s by the Argentine Juan Bautista Alberdi (1810-1884). Alberdi explained at that time that this philosophy had to arise out of Latin American needs and he brought up the programmatic claim that this philosophy had to be social and political (Alberdi [1842] 1978, p. 12). The question of identity and the so-called 'authenticity' of thinking moved into the center of the Latin American intellectual discourse (Traine 1997, pp. 78f). After the Latin American independence movements (1810-1824), two trends could be distinguished. One trend was characterized by the orientation towards Europe and the United States and to negate its own colonial past. On the other hand, there was an opposite trend marked by the systematic refusal of 'alien' cultural assets.

In 1968/69, the Peruvian philosopher Augusto Salazar Bondy (1925-1974) formulated new answers to the above-mentioned question. This turn led to liberation philosophy which emerged out of "American philosophy" (Fornet-Betancout 1997). Salazar Bondy argued that the shortcomings of "American philosophy" resulted from the cultural situation. He presented Latin American culture as a failed product, as an alienated culture which reproduced "inauthenticity" since it was affected by foreign values (Fornet-Betancout 1997, p. 248). The philosophical or rather cultural "inauthenticity" on the other hand was rooted in the political and economic situation which Salazar Bondy identified with terms like "underdevelopment" and "dependency". He called it a deformation resulting from a long historical process of colonialism and domination. The parallels to dependency theory are obvious. Based on this perspective, Salazar Bondy argued: 
The Philosophy to be developed must not be a variation of any world view belonging to the actual centers of power. [ ... ] It is necessary [ ... ] to encourage a kind of thinking which is rooted in the historical-social reality of our communities [... ] and which serves as means to abolish underdevelopment and domination which characterizes our historical situation. ${ }^{11}$

Common to the historical era Salzar Bondy was living in, his argumentation corresponded to a cultural essentialism, it was based on the belief that something like a 'pure' Latin American thinking or 'pure' European thinking would exist. In summary, the emergence of liberation theology has to be understood in the broader context of Latin American intellectual history.

\section{Dependency Relations in the Catholic Church}

Without a doubt, liberation theology emerged in a situation of domination and dependence- - this situation was not new, but the awareness of this situation increased at the end of the 1960s. This was favored by the failure of the then-dominant paradigms of development. In particular, the "Alliance of Progress" initiated by the USA, which aimed at the 'development' of Latin American countries and the containment of revolutionary movements, came more and more under criticism for the increasing dependency of Latin America.

The emphasis on Latin American originality was closely connected to the relationship of Latin America to Europe and to the United States, which was perceived in economic, political, cultural, and academic terms as a relationship of dependence. This specific characteristic of the Latin American-European relationship was reflected within the Catholic Church and its theological discourse. The Chilean cardinal Raúl Silva Henríquez explained, for example, with reference to the Second Vatican Council, that Chilean theologians started a "dialogue between equals" with European theologians (Silva Henríquez and Cavallo 1991, p. 2). This statement indicates that a meeting at eye-level was not regarded as self-evident. This impression becomes even more apparent in a statement by the Argentine cardinal Eduardo Pironio, at that time general secretary of the Latin American Episcopal Conference (CELAM). In preparation of the episcopal synode in 1971, Pironio explained:

The Church in Latin America has its own character and because of that it will have its particular voice on the next synod. [ ... ] In other occasions, we, the bishops of Latin America, waited diffidently for the bishops of the more ancient churches to present their view; based on an excessive inferiority complex we always doubted the failings [sic] of our own ideas. ${ }^{12}$

The situation of the Catholic Church in most countries of Latin America was characterized by very scarce resources. In this context, the role of Catholic relief organizations of the Global North should be mentioned. The German relief organization Misereor, for example, had a strong impact on the Catholic Church in Latin America by deciding for or against financial support for specific projects. ${ }^{13}$ Also important was the role of foreign priests, who could realize their projects financially backed by their native countries. Because of these financial resources, foreign priests had more options open to them than the native clergy. This could come along with a loss of control of the local church. ${ }^{14}$ The perception of dependency relationships by Latin American theologians and clerics resulted from the given economic relationship and the structures of decision-making within the Catholic Church.

Last but not least, the emergence of liberation theology also has to be seen in the global context of decolonization and the emergence of global movements such as EATWOT, the Ecumenical Association of Third World Theologians, founded in 1976 in Daressalam, Tanzania. The criticism by Latin American theologians of European theology was mirrored in the closing communique of EATWOT in Daressalam which stated that the churches of the Third World are dominated by European and North American theologies that do not correspond to the reality of other parts of the world (Nehring and Tielesch 2013, p. 44). 
The emergence of these contextual theologies came along with a massive critique of Missiology, the theological sub-discipline which dealt with the missionary activity in the colonial world and therefore, especially in its foundational period around the turn of the 20th century, had an ambivalent relation to colonialism. These developments led to a theological paradigm shift which was linked with the attempt to decolonize theology and provided a basis for the emergence of intercultural theology in the 1970s (Gruber 2018, pp. 11-15, 23-27, 36-37).

\section{Liberation Theology as a Challenge of European Theological Hegemony}

From the 1960s, the awareness of dependency relations in Latin America increased. The "Alliance of Progress" resulted from the economic and political dependency on the USA; within the Church, in contrast, it referred on one hand to the financial and on the other hand also to the theological dependency on Europe. The historical context of the intellectual development in Latin America indicates that liberation theology can be understood as a reaction to the perceived dependency relationships. To put it bluntly, liberation theology may be described as a reaction to European 'theological imperialism', a term which is used here to describe the perception of Latin American theologians and clerics. ${ }^{15}$ Therefore, liberation theology was both a new kind of theology and a claim to theological equity.

It was not only those Latin American theologians who studied in Europe, but also those who studied in Latin America, who received a European theological-philosophical formation. Latin American history of ideas and history of theology was not existent as a subject in seminaries and departments of theology in Latin America until 1968. Thus, academic theology was, in a Latin American perspective, for a long time exclusively European theology. The Chilean theologian and Jesuit Fernando Montes, for example, explained that Latin American theology was a "poor copy of European theology" until the 1960s. ${ }^{16}$ There are numerous references indicating that the dissociation and emancipation from Europe was crucial within liberation theology. Samuel Silva-Gotay, for example, wrote about liberation theology:

It is [ ... ] the rejection of the Theology of rich countries as the one and only theology of the Church; it is the De-Europeanization of Theology in a world which is not the property of those who took possession of it at a certain point of history. (Silva-Gotay 1995, p. XXI)

Enrique Dussel explained of liberation theology that liberation referred to the subjection which began 500 years ago with the conquest of Latin America and which has not finished yet (Dussel 1997, p. 18).

Nevertheless, there is a certain ambivalence: the rejection of European models resulted, last but not least, from the former compliance with exactly those models. It is a crucial problem of all categories of difference, be it race, class, gender, or coloniality, that the power which is ascribed on the basis of these categories is not only accepted and affirmed by those who benefit from this ascription, but also by those who are damaged, since they are denied power. This phenomenon is one of the characteristics which connects the various categories of difference. Therefore, it is not astonishing that Gustavo Gutiérrez seemed to address, in his book Teología de la Liberación, the progressive North American and European theology, but not his own tradition of culture (Fornet-Betancout 1997, p. 254).The German protestant theologian Jürgen Moltmann noticed that, reading the book by Gutiérrez, one learns a lot about Europe, but little about Latin America. ${ }^{17}$ How to explain the ambivalence in the writings of Gutiérrez and other theologians of liberation? It is to be assumed that Latin Americans could not elude the European interpretation of their situation as underdeveloped, unmodern, and so forth. These are interpretations which they partly adopted because of their European formation. Their effort to reinterpret their own situation, their striving for the development of their own concepts was therefore characterized by ambivalence. They did not only fight against common interpretations in European heads, but they had to get rid of European interpretations in their own heads. Since the matter was not only the liberation from the former interpretation, but also the challenge of the 
hegemony of European theology, this challenge could not take place but in dialogue with European theologians.

In this context, the social background of academic liberation theologians should be taken into account. It cannot be dismissed that the majority of theologians of liberation who identified with the poor and oppressed and protested against this poorness, were not poor themselves, but usually belonged to the upper class. ${ }^{18}$ The same was true for dependency theorists or philosophers of liberation. ${ }^{19}$ This is not a big surprise since the prerequisite for becoming aware of the dependency on Europe and the imbalance of power was the intimate knowledge of European thinking and linked to that, the reflection on the claim of European concepts being universal. ${ }^{20}$ It was in particular the upper class who had access to higher education. This shows that the described self-conception cannot be understood, of course, as the sole Latin American self-conception, but the self-conception of a limited, well-educated group of Latin Americans.

\section{Postcolonialism and Decoloniality}

In a postcolonial perspective, liberation theology can be understood as an act of "provincializing Europe" as was suggested by Dipesh Chakrabarty (2000). The universality claimed by European theology was accepted beyond European borders until the emergence of liberation theology. To dismiss the idea of universalism would make of European theology a provincial theology, a theology which arose in and for a European context. ${ }^{21}$ If the "provincializing" of Europe should not only take place in the heads of liberation theologians, it depended on the willingness of Europeans to become provincialized. For this process there was a need on both sides of the Atlantic for cultural brokers. Those European theologians who were open-minded about a pluralism of theologies and who were aware of Europeans' own hegemonic position took a step toward the "provincializing" of Europe. ${ }^{22}$

This is why it is problematic to speak about a first wave of Western European liberation theology in the first half of the 20th century as Gerd-Rainer Horn suggested to do (Horn 2008, p. 301). By using the term liberation theology for the theological developments in Western Europe, Horn ignores the meaning of liberation theology as a reaction to the hegemonic position of the church and theology of Europe, a hegemonic position which might be underpinned by Horn's reinterpretation of the term liberation theology.

The named Latin American intellectual movements show similarities to postcolonial approaches. Fernando Coronil even calls dependency theory one of Latin America's most significant contributions to postcolonial thought (Coronil 2008, p. 399). Postcolonial theory as well as the said Latin American intellectual approaches focus on the continuity of epistemological, economic, and political (post-)colonial relationships of power and dominance (Castro Varela and Dhawan 2015, p. 318). They have an interventionist character in common, since they challenge precisely those relationships, challenge Eurocentrism, and aim to change both political and epistemological structures. In the introduction of the volume Coloniality at Large. Latin America and the Postcolonial Discourse by Mabel Moraña, Enrique Dussel, and Carlos Jáuregui, liberation theology is called an epistemological and theoretical critique of colonialism which offered a new framework to rethink the articulation of religion and politics (Moraña et al. 2008, p. 14). All this indicates that liberation theology can be understood as a precursor of postcolonial theology. ${ }^{23}$

Nevertheless, within postcolonial theory, Latin America was, for a long time, marginalized. This was probably also due to the English-speaking context of postcolonial studies. In the current academic discourse, representatives of Latin American studies tend to distance themselves from postcolonial theory. One of their arguments for doing so is the so-called Latin American 'exceptionalism', referring to the differences of colonialism in Latin America compared to Asia or Africa, for example, the early Latin American independence in the first half of the 19th century. ${ }^{24}$ Instead of postcolonial approaches, several representatives of Latin American studies-such as most authors of the mentioned volume Coloniality at Large-prefer approaches denominated decoloniality, which are mostly based on the 
concept of coloniality introduced by the Peruvian sociologist Aníbal Quijano (Castro Varela and Dhawan 2015, p. 318).

According to Quijano, coloniality means structures and processes which were produced by colonial relations and still characterize the current global relationships of power and dominance. Among the concepts of decoloniality are "coloniality of power" (Quijano) and "colonial difference" (Mignolo) ${ }^{25}$ Representatives criticize the prefix 'post' of postcolonialism suggesting that it implies that colonial times have passed. This seems to be a common misunderstanding, since a central objective of postcolonialism is precisely to analyze the consequences of colonial rule. All in all, the dividing line between postcolonialism and decoloniality is difficult to understand, since there seems to be more similarities than differences. ${ }^{26}$ Therefore, it seems justified to me to analyze Latin American developments both by decolonial and postcolonial approaches.

\section{The Content and the Relationship Aspect in the Transatlantic Academic Discourse}

To understand the transatlantic discourse between Latin American and European theologians, it may be useful to distinguish between the content and the relationship aspect in communication processes as suggested by Paul Watzlawick et al. ([1969] 2007, pp. 5356). This distinction is one of five basic axioms of Watzlawick's communication theory and indicates that the relationship aspect classifies the content aspect and is therefore a metacommunication. In the relationship aspect of communication, the partners of the communication process interchange their definition of their relationship and therefore, implicitly, their self-conceptions.

The communication process about liberation theology mirrored the hegemonic relationship between Latin American and European theology. As already shown in reference to the writings of Latin American theologians, the relationship aspect was of crucial importance since these writings often refer to the (former and remaining) dependency on European theology. Regarding the relationship aspect of the communication, Latin American liberation theologians challenged precisely the hegemonic structure of the academic transatlantic discourse. This is the reason why liberation theology was occasionally favored even by those Latin American theologians who did not fully agree with its theological and political content. It was the relationship aspect of the discourse they sympathized with and not the content one.

On the other hand, the relationship aspect also became apparent in the statements of European theologians, by those theologians who criticized liberation theology as well as by those who were sympathetic to it. The Belgian Dominican and theologian Edward Schillebeeckx who sympathized with liberation theology and defended it, when it was condemned by the instruction of the Congregation for the Doctrine of the Faith in 1984, argued for example that liberation theology was a recent theology which therefore shows "in some parts teething troubles" (Schillebeeckx 1985, p. 102). This statement implies the idea that the developments in the extra-European world can be classified as a teleological reenactment of European history. This recalls the idea of Chakrabarty that the colonial world was put into the "waiting room of history" since it is usually classified as premodern in the European concept of history which implies a Western construction of time differentiating between modern and premodern (Chakrabarty 2000, p. 7). We could ask whether some Europeans sent liberation theologians-whether with or without intention-to the kindergarten of theological thinking. In the case of Schillebeeckx, he definitely did it without intention, since he appreciated liberation theology for its inspiration to European theology and belonged, without a doubt, to the group of the here-called cultural brokers. However, it is very unlikely that possible deficiencies, for example of the political theology in Europe, would have been explained by a metaphor referring to children like "teething troubles". This argumentation is an example of how local histories and alternative epistemologies are treated as if they were experimental constructs (Moraña et al. 2008, p. 16). In the relationship aspect, Schillebeeckx showed a willingness to give up the European theological 
hegemony in the medium-term; nevertheless, he pointed to the assumed "immaturity" of Latin American theological ideas.

While the statement of Schillebeeckx is a comparison "old versus young" or "mature versus immature", we can find a confrontation between "civilized versus uncivilized" in the following citation of Wilhelm Weber.

The immense theological achievement of a clear distinction between a sacral and a mundane sphere, between creation and salvation, [ ... ] between this world and the other world is frivolously abandoned. Therefore they [the liberation theologians, A.S.] replace archaic religious ideas as for example a natural animism by the modern variation of a social animism. The gods do not sit any longer on trees or in rivers, but have their place within class, race, at the base or where ever. (Weber 1984, p. 158)

Weber delegitimized liberation theology by equalizing it with a "social animism" and in doing so denied its theological status. He claimed liberation theology to be deficient and linked this deficiency with its provenance. In any case, Weber dispensed with a discussion based on arguments about the concepts of liberation theology, such as for example the relationship between liberation and salvation or this world and the other world. The relationship aspect in Weber's statement clearly dominates the content aspect by leaving the factual level aside and implicitly stating the incompetence of liberation theologians.

These statements about liberation theology can be interpreted as a reaction to the presentation of Latin American liberation theologians of how they see themselves and their relationship to Europe. According to Watzlawick, Beavin, and Jackson, there are three types of possible reactions to this kind of presentation of the communication partner, namely confirmation, rejection, and disconfirmation (Watzlawick et al. [1969] 2007, pp. 79-91). The reaction of Schillebeeckx could be understood as confirmation, since he feeds back that he accepts the others' presentation of the relationship and of self, this is to say the demand of Latin American theologians to be recognized as equal communication partners. Nevertheless, Schillebeeckx obviously assumed a lack of 'maturity' in Latin American ideas. Weber's reaction, on the other hand, is a rejection, since he disagrees with the presentation of self of liberation theologians. He denies that they are communication partners at eyelevel. The reaction of those critics who refused to deal with liberation theology since they did not accept it as an independent concept, as described in the first part of this article, can be understood as disconfirmation. That is to say that those critics ignored the reality of the Latin American academics' presentation of self. A disconfirmation questions, therefore, in a certain way the existence of the other and rejects him or her as communication partner (Watzlawick et al. [1969] 2007, p. 86).

\section{Conclusions}

With reference to relationship patterns, liberation theology can be understood as a reaction to the hegemonic position of Europe, both in the Catholic Church and within the transatlantic academic discourse. Liberation theologians (not only Latin American, but also European ones) challenged these structures and shifted the position of Latin America in the frame of ecclesiastical and theological thinking. This resulted last but not least from the adoption of liberation theology in the Roman center of the institutional Church.

The strong relationship aspect of transatlantic academic discourse was not necessarily reflected by the authors. The meta-communication revealed the self-conception of the communication partner and how they saw their relationship to the other. In the transatlantic discourse, the meta-communication evidences that hegemonic structures were perpetuated within the academic theological system in the 1960s and 1970s and that liberation theology aimed to change precisely these structures. Nevertheless, and in spite of the hegemonic structures, the discourse was also characterized by a constructive dialogue, close contacts, and the translation of ideas. Therefore, those theologians who contributed to a constructive theological discourse on both sides of the Atlantic are called here cultural brokers. 
Liberation theology—-together with other intellectual movements in Latin Americainitiated a process of reflection within the academic discourse about the imbalance of power that remained after the end of colonialism. Central assumptions of this discussion can be found today in postcolonial studies and decoloniality studies. However, the process of reflection is impeded by the fact that a central feature of academic self-definition is to stick to scientific and verifiable rules. Because of that, academics tend to believe mistakenly that academic writing cannot reproduce imbalances of power and epistemic inequality. This blindness for the colonial difference can be described as colonial bias. I understand my role as a historian and as a translator between the worlds who translates a specific knowledge, or rather a way of perception from one region to make it accessible for another region. By doing so, this article intends to correspond to the suggestion of Doris Bachmann-Medick who ascribes precisely this role of translation to the area studies (Bachmann-Medick 2015, p. 21).

This article aims to contribute to an awareness raising for the colonial bias and therefore it addresses in particular a European readership. Indeed, it would be a kind of European hubris to explain Latin Americans their historical need for emancipation of Europe. Nevertheless, since my article claims to explain one of the ways of perception of Latin American theologians in the 1960s and 1970s, I have to react to the crucial question of postcolonial theory, whether a non-reductionist representation of the other is possible at all (Castro Varela and Dhawan 2015, p. 120). This question is certainly justified, especially with reference to the historiography of former colonized regions. Nevertheless, the conflict that the represented other never totally agrees with his or her representation in academic writings does not only exist with reference to the representation of Latin Americans by Europeans, but is a general problem of contemporary history. Historiography is always a construction, an interpretation of historical sources, which of course could also be interpreted in another way.

Funding: This research was funded in part by the Cluster of Excellence "Religion and Politics in Pre-Modern and Modern Cultures" of the University of Münster.

Conflicts of Interest: The author declares no conflict of interest.

\section{Notes}

1 For a historiographical review of the Latin American history of ideas see (Paltí 2009, pp. 593-95).

2 About the relation between liberation theology and the catholic social doctrine see (Antoncich 1990).

3 With reference to the meaning of decree 4 for the social and political attitudes of Jesuits in Latin America see (Schnoor 2016).

4 See (Kruip 1997, p. 47). Kruip refers to a number of studies, among them: Rauscher, Anton. 1970. "Zur Problematik der politischen Theologie". Münchener Theologische Zeitschrift 21: 348-56; Roos, L. 1981. "Politische Theologien und katholische Soziallehre. Versuch einer historisch-vergleichenden Analyse im Interesse eines besseren gegenseitigen Verständnisses". Internationale Katholische Zeitschrift 10: 131-45.

5 With reference to the concept of translation, see for example (Bachmann-Medick 2009).

6 See for example (Lässig 2016, p. 36).

7 (Metz [1973] 1976, p. XI). Unless otherwise indicated, all translations are my own.

8 Rahner, “Vorwort". In Befreiende Theologie (Rahner et al. 1977, p. 8).

9 Among the relevant writings of Dependency theory are Cardoso and Faletto (1969), Dependencia y desarrollo; dos Santos (1972), Dependencia y Cambio Social; Frank (1968), Kapitalismus und Unterentwicklung.

10 See (McGovern 1989, pp. 116ff). The close relationship between liberation theology and dependency theory became looser in the 1980s because of the criticism of dependency theory.

11 Salazar Bondy, Existe una filosofía de nuestra América?, Mexico, 1968, 119. Cited in (Fornet-Betancout 1997, p. 248).

12 Cited in "Carta del embajador de Chile ante la Santa Sede René Rojas Galdames al Ministerio de Relaciones Exteriores de Chile", 30.09.1971, Archivo del Ministerio de Relaciones Exteriores de Chile, Embajada chilena ante la Santa Sede, Nr. 35270. “La Iglesia de América Latina tiene su fisionomía propia; por lo consiguiente tendrá también en el sínodo próximo su voz determinada. [ ... . ] En otras ocasiones los Obispos de América Latina esperábamos con tímidez que se pronunciaran los Obispos de las Iglesias más antiguas; en un excesivo complejo de inferioridad desconfiábamos siempre de la imperfección [sic] de lo nuestro." The quotation does not seem to be fully comprehensible. It seems that 'perfección' would make more sense than 'imperfección'. In the English translation, this would be 'coherence' instead of 'failings'. 
13 It became obvious that this possible influence was not limited to projects, when a group of Latin American bishops argued for the ordination of married men to solve the problem of priest shortage. The German episcopal conference refused thereupon the support of these Latin American bishops. This led to internal conflicts in Misereor, since the responsible department rejected the request. Vgl. Interview with Klaus Kick; 10.09.2008, Lima, Peru; Interviewer: Antje Schnoor. Klaus Kick was consultant in Misereor between 1978 and 1984 for Chile, Argentina, Brasil, Paraguay, and Uruguay.

14 The number of foreign priests increased since the 1950s. This was due to the apostolic letter Fidei Donum (1957). Already in the apostolic letter Ad Ecclesiam Christi (1955), the Holy See called for sending priests to Latin America to compensate the local priest shortage. In 1960, in Chile, for example, about $50 \%$ of priests came from foreign countries. Foreign religious figures have been represented above-average in favelas.

15 'Theological imperialism' can be understood as a form of cultural imperialism. Cultural imperialism is, according to Johan Galtung, one of five types of imperialism (economic, political, military, communication and cultural imperialism). See Galtung (1971), "A Structural Theory of Imperialism".

16 See Interview with Fernando Montes SJ.; 30.07.2008, Santiago de Chile; Interviewer: Antje Schnoor. Fernando Montes was president of the University Alberto Hurtado in Santiago de Chile between 1998 and 2016.

17 See (Moltmann 1976, p. 756). However, Juan Luis Segundo wrote an (unpublished) answer to that letter asking-obviously with some irony-whether Moltmann was looking for some Latin American exotic touch. See (Westhelle 2013, p. 172).

18 Philipp Berryman comes right to the point by stating that it was the non-poor who proclaimed the option for the poor. See (Berryman 1989, p. 79).

19 Therefore, it is inopportune to say about those academics—as Enrique Dussel does in the case of philosophers of liberation-that they were localized within subaltern groups. See (Dussel 2008, p. 340).

20 Dipesh Chakrabarty describes a similar conflict for the Indian academic history when it tries to present the difference and originality of the own history and in doing so cannot completely avoid using European historical concepts. See (Chakrabarty 2002, pp. 283-312). Representatives of the "Subaltern Studies Group" are sometimes criticized to be affected by US-American or European culture and usually belong to universities in the USA or Europe, which contradicts the propagation and the claiming of non-Western perspectives. This criticism ignores that it was particularly the knowledge of the European system of thought which facilitated challenge the European concepts and knowledge systems, as described for the Latin American theologians.

21 In this context, it may be mentioned that the term "contextual theology", which was born in the 1970s due to the rejection of the universalist claim of traditional theology, is used until today almost exclusively for theologies of regions in the Global South. See (Nehring and Tielesch 2013, p. 12).

22 This was true for example for Karl Rahner, Hans Zwiefelhöfer, and other authors of the volume "Befreiende Theologie" (Rahner et al. 1977).

23 For postcolonial theologies, see, e.g., the already-mentioned volume by Nehring and Tielesch, Postkoloniale Theologien. Bibelhermeneutische und kulturwissenschaftliche Beiträge.

24 Moreover, there is a long-standing debate whether or not the term "colonies" should be applied to Spanish America. About this debate see (Mazzotti 2008, pp. 79f).

25 See (Quijano 2008; Mignolo 2008). According to Quijano, coloniality of power is based on the ethnic classification of the world population as the pivot of the organization of capitalist dominance.

26 For a discussion of the differences and similarities of postcolonialism and decoloniality, see (Kastner and Tom 2012).

\section{References}

Alberdi, Juan Bautista. 1978. Ideas Para Presidir la Confección de un Curso de Filosofía Contemporánea. Cited by Leopoldo Zea. Filosofia Latinoamericana. México City: Editorial Trillas. First published 1842.

Antoncich, Ricardo S. J. 1990. Teología de la Liberación y Doctrina Social de la Iglesia. In Mysterium Liberationis. Conceptos Fundamentales de la Teología de la Liberación. Edited by Ellacuría S. J. Ignacio and Sobrino S. J. Jon. Madrid: Trotta, pp. 145-68.

Bachmann-Medick, Doris. 2009. Introduction. The translational turn. Translation Studies 2: 2-16. [CrossRef]

Bachmann-Medick, Doris. 2015. Transnational und Translational. Zur Übersetzungsfunktion der Area-Studies. CAS Working Paper Series; Berlin: Center for Area Studies.

Berryman, Phillip. 1989. Liberation Theology. Essential Facts about the Revolutionary Movement in Latin America and Beyond. New York: Pantheon Books.

Buden, Boris, Nowotny Stefan, and Simon Sherry. 2009. Cultural Translation. An Introduction to the Problem, and Responses. Translation Studies 2: 196-219. [CrossRef]

Cardoso, Fernando H., and Enzo Faletto. 1969. Dependencia y desarrollo en América Latina. Ensayo de interpretación sociológica. Mexico: Buenos Aires.

Castro Varela, María do Mar, and Nikita Dhawan. 2015. Postkoloniale Theorie. Eine kritische Einführung. Bielefeld: Transcript.

Chakrabarty, Dipesh. 2000. Provincializing Europe: Postcolonial Thought and Historical Difference. Princeton: Princeton University Press.

Chakrabarty, Dipesh. 2002. Europa provinzialisieren. Postkolonialität und die Kritik der Geschichte. In Jenseits des Eurozentrismus. Postkoloniale Perspektiven in den Geschichts- und Kulturwissenschaften. Edited by Sebastian Conrad and Shalini Randeira. Frankfurt am Main: Campus, pp. 183-312.

Collet, Giancarlo. 1994. Befreiungstheologie. $L T h K^{3}$ 2: 130-34. 
Coronil, Fernando. 2008. Elephants in the Americas? Latin American Postcolonial Studies and Global Decolonization. In Coloniality at Large. Latin America and the Postcolonial Debate. Edited by Mabel Moraña, Enrique Dussel and Carlos A. Jáuregui. Durham and London: Duke University Press, pp. 396-416.

dos Santos, Theotonio. 1972. Dependencia y Cambio Social. Santiago de Chile: CESO.

Dussel, Enrique. 1995. Theologie der Befreiung und Marxismus. In Mysterium Liberationis. Grundbegriffe der Theologie der Befreiung. Edited by Ellacuría S. J. Ignacio and Sobrino S. J. Jon. Luzern: Edition Exodus, pp. 99-130.

Dussel, Enrique. 1997. Zur sozio-historischen Bedeutung der Befreiungstheologie. Überlegungen zu weltgeschichtlichem Ursprung und Kontext. In Befreiungstheologie. Kritischer Rückblick und Perspektiven für die Zukunft. Edited by Raúl Fornet-Betancourt. Mainz: M.-Grünewald Verlag, pp. 9-18.

Dussel, Enrique. 2008. Philosophy of Liberation, the Postmodern Debate, and Latin American Studies. In Coloniality at Large. Latin America and the Postcolonial Debate. Edited by Mabel Moraña, Enrique Dussel and Carlos A. Jáuregui. Durham and London: Duke University Press, pp. 335-49.

Frank, André Gunder. 1968. Kapitalismus und Unterentwicklung in Lateinamerika. Frankfurt am Main: Europäische Verlagsanstalt.

Galtung, Johan. 1969. Violence, Peace and Peace Research. Journal of Peace Research 6: 167-91. [CrossRef]

Galtung, Johan. 1971. A Structural Theory of Imperialism. Journal of Peace Research 8: 81-117. [CrossRef]

Gruber, Judith. 2018. Intercultural Theology. Exploring World Christianity after the Cultural Turn. Göttingen: Vandenhoeck \& Ruprecht.

Gutiérrez, Gustavo. 1976. Theologie der Befreiung. München: Kaiser.

Horn, Gerd-Rainer. 2008. Western European Liberation Theology. The First Wave (1924-1959). Oxford: Oxford University Press.

Kastner, Jens, and Waibel Tom. 2012. Dekoloniale Optionen. Argumentation, Begriffe und Kontexte dekolonialer Theoriebildung. In Epistemischer Ungehorsam. Rhetorik der Moderne, Logik der Kolonialität und Grammatik der Dekolonialität. Edited by Walter D. Mignolo. Wien: Verlag Turia + Kant, pp. 7-42.

Kruip, Gerhard. 1997. Die Rezeption der Theologie der Befreiung in der Christlichen Sozialethik in Deutschland. In Befreiungstheologie. Kritischer Rückblick und Perspektiven für die Zukunft. Edited by Raúl Fornet-Betancourt. Mainz: M.-Grünewald Verlag, pp. 41-66.

Lässig, Simone. 2016. The History of Knowledge and the Expansion of the Historical Research Agenda. Bulletin of the German Historical Institute 59: 29-58.

Mazzotti, José Antonio. 2008. Creole Agencies and the (Post)Colonial Debate in Spanish America. In Coloniality at Large. Latin America and the Postcolonial Debate. Edited by Mabel Moraña, Enrique Dussel and Carlos A. Jáuregui. Durham and London: Duke University Press, pp. 77-110.

McGovern, Arthur F. 1989. Liberation Theology and Its Critics. Toward an Assessment. New York: Orbis Books.

Metz, Johann Baptist. 1976. Vorwort zur Deutschen Ausgabe. In Theologie der Befreiung. Edited by Gustavo Gutiérrez. Mainz: Kaiser, pp. I-XII. First published 1973.

Mignolo, Walter D. 2008. The Geopolitics of Knowledge and the Colonial Difference. In Coloniality at Large. Latin America and the Postcolonial Debate. Edited by Mabel Moraña, Enrique Dussel and Carlos A. Jáuregui. Durham and London: Duke University Press, pp. 225-58.

Moews, Andrea-Isa. 2002. Eliten für Lateinamerika. Lateinamerikanische Studenten an der Katholischen Universität Löwen in den 1950er und 1960er Jahren. Köln: Böhlau.

Moltmann, Jürgen. 1976. Offener Brief an José Miguez Bonino. Evangelische Kommentare 9: 755-57.

Moraña, Mabel, Enrique Dussel, and Carlos A. Jáuregui. 2008. Coloniality and its Replicants. In Coloniality at Large. Latin America and the Postcolonial Debate. Edited by Mabel Moraña, Enrique Dussel and Carlos A. Jáuregui. Durham and London: Duke University Press, pp. 1-20.

Nehring, Andreas, and Simon Tielesch. 2013. Theologie und Postkolonialismus. Zur Einführung. In Postkoloniale Theologien. Bibelhermeneutische und kulturwissenchaftliche Beiträge. Edited by Andreas Nehring and Simon Tielesch. Stuttgart: Kohlhammer, pp. 9-45.

Paltí, Elías José. 2009. Beyond Revisionism: The Bicentennial of Independence, the Early Republican Experience, and Intellectual History in Latin America. Journal of the History of Ideas 70: 593-614. [CrossRef]

Quijano, Aníbal. 2008. Coloniality of Power, Eurocentrism, and Social Classification. In Coloniality at Large. Latin America and the Postcolonial Debate. Edited by Mabel Moraña, Enrique Dussel and Carlos A. Jáuregui. Durham and London: Duke University Press, pp. 181-224.

Rahner, Karl, Christian Modehn, and Hans Zwiefelhofer. 1977. Befreiende Theologie. Der Beitrag Lateinamerikas zur Theologie der Gegenwart. Stuttgart: W. Kohlhammer.

Fornet-Betancout, Raúl. 1997. Zur Artikulation in der Philosophie: Wirkung der Befreiungstheologie auf die Philosophie. In Befreiungstheologie. Kritischer Rückblick und Perspektiven für die Zukunft. Mainz: M.-Grünewald Verlag, pp. $244-63$.

Schillebeeckx, Edward. 1985. Una óptica equivocada. Misión Abierta 1: 100-2.

Schnoor, Antje. 2011. Zwischen jenseitiger Erlösung und irdischem Heil. Die Rezeption der Befreiungstheologie in der Gesellschaft Jesu. Archiv für Sozialgeschichte 51: 419-43.

Schnoor, Antje. 2013. Umkämpfte Gewalt. Jesuitische Perspektiven auf die soziale Ordnung, Chile 1968-1973. In Die Katholische Kirche und Gewalt. Europa und Lateinamerika im 20. Jahrhundert. Edited by Silke Hensel and Hubert Wolf. Böhlau: Köln/Weimar/Wien, pp. 255-75. 
Schnoor, Antje. 2016. Gehorchen und Gestalten. Jesuiten zwischen Demokratie und Diktatur in Chile (1962-1983). Frankfurt am Main: Campus.

Silva Henríquez, Raúl, and Ascanio Cavallo. 1991. Memorias Cardenal Raúl Silva Henríquez. Santiago de Chile: Ediciones Copygraph, vol. II.

Silva-Gotay, Samuel. 1995. Christentum und Revolution in Lateinamerika und der Karibik. Die Bedeutung der Theologie der Befreiung für eine Soziologie der Religion. Frankfurt am Main: Peter Lang.

Traine, Martin. 1997. Einleitende Bemerkung: Befreiung des Textes. Befreiungstheologie und Rezeptionstheorie. In Befreiungstheologie. Kritischer Rückblick und Perspektiven für die Zukunft. Edited by Raúl Fornet-Betancourt. Mainz: M.-Grünewald Verlag, pp. 71-83.

Vekemans, Roger. n.d. El Centro Bellarmino, Unpublished Manuscriped.

Wagner, Birgit. Cultural Translation: A Value or a Tool? Let's start with Gramsci! Available online: www.goethezeitportal.de/ kommunikation/diskussionsforen/postkoloniale-studien.html (accessed on 5 January 2018).

Watzlawick, Paul, Janet H. Beavin, and Don D. Jackson. 2007. Menschliche Kommunikation. Formen, Störungen, Paradoxien. Huber: Bern. First published 1969.

Weber, Wilhelm. 1984. Wenn Aber das Salz Schal wird ... Der Einfluss Sozialwissenschaftlicher Weltbilder auf Theologisches und Kirchliches Sprechen und Handeln. Würzburg: Echter.

Westhelle, Vítor. 2013. Offene Ränder. Repräsentation, Hybridität und Transfiguration. In Postkoloniale Theologien. Bibelhermeneutische und kulturwissenschaftliche Beiträge. Edited by Nehring Andreas and Simon Tielesch. Stuttgart: Kohlhammer, pp. 165-86. 